\title{
Work-Life Balance and Organizational Performance: The Mediating Role of Organizational Citizenship Behavior
}

\section{N. Thevanes ${ }^{1 \times(D)}$ \\ S. Harikaran ${ }^{2}$}

'Assistant Lecturer, Trincomalee Campus, Eastern University, Sri Lanka.

Email:nadesthev@gmail.com Tel:94778583723

${ }^{2}$ Lecturer, Vavuniya Campus of the University of Jaffna, Sri Lanka.

Email:harikarans8@gmail.com Tel:94776660601

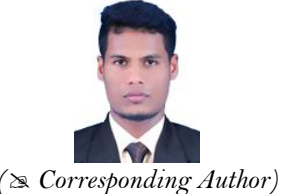

\section{Abstract}

Previous studies rarely examined the relationships among work-life balance, organizational citizenship behavior (OCB) and organizational performance. Moreover, most studies neglect the mediating effect of $\mathrm{OCB}$ in the relationship between work-life balance and organizational performance. Hence, this paper aims to examine the relationships among work-life balance, OCB and organizational performance and the mediating effect of $\mathrm{OCB}$ in the relationship between work-life balance and organizational performance. In order to achieve the study objectives, primary data were collected from 166 employees in selected private banks which are operating in Batticaloa district of Sri Lanka. The simple mediation analysis was used to test the research model. Findings of the study revealed that, there are positive and significant relationships exist among the study variables. Moreover, empirical finding of the study indicated that OCB mediates the relationship between work-life balance and organizational performance. The empirical findings of the study support the theoretical argument of the study. The current study is considered to be vital in understanding the empirical knowledge regarding the relationships among work-life balance, organizational citizenship behavior (OCB) and organizational performance.

Keywords: Work-life balance, Citizenship behavior, Organization, Performance, Bank, Employee.

JEL Classification: M10 Business Administration: General.

Citation | N. Thevanes; S. Harikaran (2020). Work-Life Balance and Organizational Performance: The Mediating Role of Organizational Citizenship Behavior. Asian Journal of Social Sciences and Management Studies, 7(4): 280-287.

\section{History:}

Received: 18 September 2020

Revised: 9 October 2020

Accepted: 23 October 2020

Published: 5 November 2020

Licensed: This work is licensed under a Creative Commons

Attribution 3.0 License (cc)

Publisher: Asian Online Journal Publishing Group
Acknowledgement: Both authors contributed to the conception and design of the study.

Funding: This study received no specific financial support.

Competing Interests: The authors declare that they have no conflict of interests.

Transparency: The authors confirm that the manuscript is an honest, accurate, and transparent account of the study was reported; that no vital features of the study have been omitted; and that any discrepancies from the study as planned have been explained.

Ethical: This study follows all ethical practices during writing.

\section{Contents}

1. Introduction

2. Literature Review

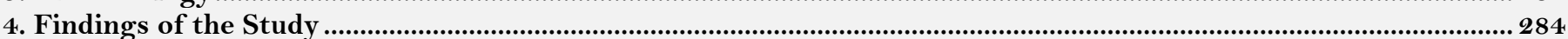

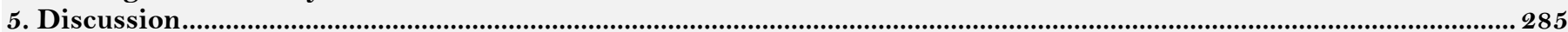

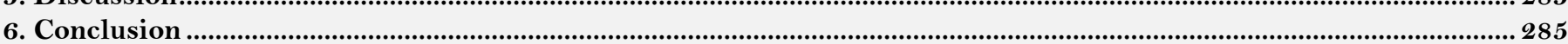

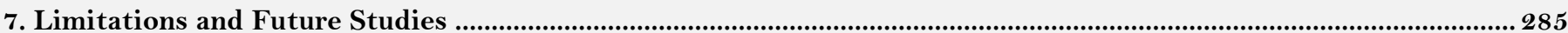

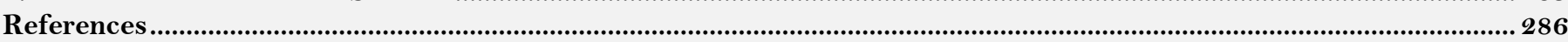




\section{Contribution of this paper to the literature}

This study focuses on relationships among work-life balance, organizational citizenship behavior and organizational performance. In the existing literature, these relationships are not clearly explored and remained unclear. Therefore, this study fills these relationship gaps in the existing literature. Especially, this study should make a direct contribution to the literature on human resource management and organizational behavior.

\section{Introduction}

In this today competitive business environment, working people are facing more significant challenges in balancing their work and family responsibilities. The typical employee in the 1960 s or 1970 showed up at a specified workplace Monday through Friday and worked for clearly defined 8- or 9-hour chunks of time. That's no longer true for a large segment of today's workforce. Employees are increasingly complaining that the line between work and non-work time has become blurred, creating personal conflicts and stress (Robbins \& Judge, 2013). In this sense, some researchers argue that, technological advancement lead to less work-life conflict by allowing them working from multiple locations, including the home through e-mails and other electronic communication methods (Hayman, 2009; Thevanes \& Mangaleswaran, 2018; Waller \& Ragsdell, 2012; Wheatley, 2012). On other hand, Robbins and Judge (2013) have explained that communication technology allows many technical and professional employees to do their work at home, in their cars and other places which away from their workplace. Hence, it is extremely difficult to get away from their jobs. Nowadays, organizations are requesting employees to work for longer hours to reach their goals and objectives. Further, they stated that creation of global organizations lead to the world never sleeps. Thus, work-life conflict is considered as contemporary issue in today world and lead to several social conflicts.

Hence, employees forced to search for a job where they can balance their work and family responsibilities to ensure the quality life (Greenhaus, Collins, \& Shaw, 2003). Recent studies suggest employees want jobs that give them flexibility in their work schedules so they can better manage work-life conflicts. Nowadays, employees seriously concern about their work-life balance before accept the job offer beyond the salary and other fringe benefits (Thevanes \& Mangaleswaran, 2018). Further, they also indicated that employees do not show interest in working in outside area beyond their home town in order eliminate the work-life conflict. Thus, organizations also increasingly required to focus work-life balance of their employees to unleash the employees' and organizational performance to ensure the sustainable competitive advantage. Any organization aiming to increase competitive advantage needs to develop an approach to human resource and work-life balance strategies that cater for the diverse needs of the workforce (Cieri, Holmes, Abbott, \& Pettit, 2005). In order to respond this issue, managers are paying a great attention on design workplaces and jobs that can help employees deal with work-life conflicts. Thus, organizations today offer a range of work-life and work-family programmes and benefits such as job sharing, work flexibility and on-site child-care designed to reduce the stress associated with balancing multiple roles (McCarthy, Cleveland, Hunter, Darcy, \& Grady, 2013).

In this context, number of scholars contributed to the understanding of work-life balance (Bardoel \& Drago, 2016; Chan et al., 2016; Fischlmayr \& Kollinger, 2010; Fleetwood, 2007; Heywood, Siebert, \& Wei, 2010; McCarthy et al., 2013). However, many scholars have conducted research studies regarding work-life balance (Edwards \& Kuruvilla, 2005; Hyman \& Summers, 2007; Winefield, Boyd, \& Winefield, 2014) organizational citizenship behavior (Kegans, McCamey, \& Hammond, 2012; Wang., 2015; Xerri \& Brunetto, 2013) and organizational performance (Khaola, 2014; Koopmans et al., 2011; Podsakoff \& MacKenzie, 1997) separately. Moreover, anecdotal evidences reveal that a very few research works are available in this area in Sri Lanka. Even though, work-life balance, organizational citizenship behavior and organizational performance are considered as the interrelated concepts. Previous studies rarely examined the relationships among these concepts theoretically as well as empirically. Moreover, most studies neglect the mediating role of OCB in the relationship between worklife balance and organizational performance.

Thus, this study focuses on relationships among work-life balance, OCB and organizational performance. In the existing literature, these relationships are not clearly explored and remained unclear. Therefore, this study fills these relationship gaps in the existing literature. Especially, this study should make a direct contribution to the literature on human resource management (HRM) and organizational behavior $(\mathrm{OB})$. Hence, the objective of this review is to explore the relationships among work-life balance, $\mathrm{OCB}$ and organizational performance and examine the mediating effects of OCB on the relationship between work-life balance and organizational performance.

This article is structured as follows. Next section provides method of review, third section presents the review of the relevant literature about work-life balance, OCB, and organizational performance and propose the hypotheses. The third section provides the methodology of this study. Lastly, we present the findings and discussion of the study and finally, it ends up with the conclusion.

\section{Literature Review}

\subsection{Relationship between Work-life Balance and Job Performance}

Researchers argued that, an organization's performance directly depends on the individuals it employs (Arulrajah \& Opatha, 2012). As an organization's competitive advantage is typically based on strong human resources, it is crucial for organizations to improve employee performance to enrich the overall organizational performance. Hence, organizations seriously focus on enhancing positive work-related attitudes (eg: job satisfaction, organizational commitment) and work-related behaviors (eg: OCB, work engagement) to unleash the job performance of employees (Meijerink, Bos-Nehles, \& de Leede, 2018).

In this context, several researchers argued that, it is possible to enhance the positive work-related attitudes and behaviors among employees through the work-life balance promoting HRM practices such as telecommuting, job sharing, flextime, etc (Bardoel \& Drago, 2016; Chan et al., 2016; Fleetwood, 2007; McCarthy et al., 2013; Winefield et al., 2014). Organizations with more satisfied employees tend to be more effective. For many companies, worklife balance seems to lead to several positive outcomes such, low turnover, less absenteeism and increased work 
engagement, OCB, in-role performance, employee productivity, job satisfaction, organizational commitment and etc (Konrad \& Mangel, 2000; Lambert, 2000; Nawab \& Iqbal., 2013; Parakandi \& Behery, 2016; Wang \& Walumbwa, 2007) which turns lead to superior organizational performance. Wheatley (2012) indicate that, worklife balance of employee providing the win-win outcomes from both employer and employees. In addition to that, Naithani (2010) has stated that organization which neglects issues related to employee work-life balance will end up with lower employee productivity and in turn will find it more difficult to improve the employee job performance. Further, Thevanes and Arurajah (2017) have identified work-life balance promoting practices as a one of the sustainable HRM practices which contributes to economic, social and environmental performance of the organizations. In this sense, for the employees who work in the home town, the work-life conflict is much less than the others whose work site is far away from home. An employee has the privilege of spending more time with his family and easily fulfills his/her family commitments. So, the employees become a vibrant team of happy and committed individuals driving the organizations towards sustainable growth (Thevanes \& Arurajah, 2017). In addition to that, Robbins and Judge (2013) revealed that organizations that don't help their people achieve worklife balance will find it increasingly difficult to attract and retain the most capable and motivated employees. Hence, organizations should give more priority to enhance the work-life balance of employees to create the satisfied, committed and retained workforce to uplift the organizational performance.

According to the above literature, this study establishes that work-life has a positive relationship with organizational performance. Therefore, this study proposes a hypothesis:

Hypothesis 1: There is a positive relationship between work-life balance and organizational performance.

\subsection{Relationship between Work-life Balance and OCB}

Nowadays, organizations are continuously implementing several strategies, initiatives and practices to enhance the employees' conscious and active participation and commitment in the organizational activities to achieve the goals and objectives. Hence, organizations increasingly required to enhance the positive employee attitudes and behaviors to improve the individual performance. In this context, OCB is considered as the crucial employee workplace behavior which has the ability to enhance the organizational performance. Further, most studies on OCB describe it as a positive and constructive behavior worthy of encouragement by supervisors and very important for clients of the organization (Kegans et al., 2012; Vigoda-Gadot \& Beeri, 2011; Wang, 2015; Xerri \& Brunetto, 2013; Zhao, Wu, Sun, \& Chen, 2012). According to Organ, Podsakoff, and MacKenzie (2006) OCB is an employee's discretionary behavior that is not directly or explicitly recognized by the formal reward system and efficiently and effectively promotes the performance of the organization. Further, some researchers stated that, going above and beyond what is expected in the workplace is referred to as organizational citizenship behaviors; these behaviors often lead to valuable contributions to the organization (Anit Somech \& Drach-Zahavy, 2004; Turnipseed \& Rassuli, 2005). If members feel that the organization supports them, they will exhibit OCBs which is beneficial for the organization (Tsui-Hsu Tsai \& Jing Lin, 2014). Thus, organizations increasingly pay attention on enhancing OCBs among employees.

Indeed, organizations turn their focus on creating, identifying and implementing several strategies and practices to foster the OCBs among the organization's employees. Higher levels of organizational support will be related to higher levels of employee engagement (Zhao et al., 2012) which in turn will result in higher levels OCBs within the organization. Lambert, Hogan, and Griffin (2008) revealed that, if staff are treated with respect and dignity then engagement in OCBs is more likely. In this sense, McCarthy et al. (2013) stated that, work-life balance is considered as the major indicator of organizational support. Further, Allen (2001) found it was important to disentangle employee perceptions of supervisory support from perceptions of organizational support or generally a climate where employees are encouraged to use work-life balance policies and programmes. In addition to that, Wang. (2015) indicated that enhancing work-life balance strategies within the organization contributes to create a positive atmosphere in the day to day correctional work environment to employees which turns lead to foster OCBs among the employees.

In this context, some researchers stated that uplifting work-life balance of employees significantly contributes to enhance the OCBs of employees (Beham, 2011; Lambert, 2000; Lambert, Kelley, \& Hogan, 2013; Pradhan, Jena, \& Kumari, 2016). The antecedents of OCB comprise employee attitudes, role perceptions, stress, job satisfaction, interpersonal trust, organizational commitment and employee mood (Moorman \& Blakely, 1995; Williams \& Shiaw, 1999). Hence, it is possible to enhance the OCBs of employees to improve these positive work attitudes among employees. In this scenario, researchers argued that ensuring the work-life balance to the employees has become a more important mechanism to exhibit positive job attitudes and behaviors (Chan et al., 2016; Galinsky, Bond, \& Hill, 2004; Konrad \& Mangel, 2000; Lambert, 2000; McNall, Masuda, \& Nicklin, 2009; Richman, 2006; Wang \& Walumbwa, 2007; WFD Consulting, 2007). Similarly, work-life balance has a positive impact on job and family satisfaction. Work-life balance, in turn, leads to both job and family satisfaction because an employee who has achieved work-life balance is most probably experiencing good functioning at work and at home with minimum inter-role conflict (Allen, 2001; Chan et al., 2016). People who are more satisfied with their jobs are more likely to engage in OCBs (Hoffman, Blair, Meriac, \& Woehr, 2007). In overall, this trend improves the OCBs of employees within the organization. In addition to that Organ et al. (2006) pointed that work-life balance appears to promote employee's engagement in OCBs which may benefit the organization through positive affectivity. However, employees with conflicting work and family demands may not always be able to go the extra mile for their organization and demonstrate high levels of OCBs as expected by their employers (Beham, 2011). In other words, improving work-life balance contributes to foster employees' OCBs within the organization by creating positive work environment and climate. However, few studies have considered the relationship between work-life balance and OCB in the past. Thus, this review considers this as a gap in the literature and wants to establish a positive relationship between work-life balance and OCBs of employee. Based on the above cited literature evidences, it can be possible to establish a positive relationship between work-life balance and OCBs. According to the above literature, this review establishes that work-life balance has a positive relationship with OCBs of employees as a second hypothesis of this review.

Hypothesis 2: There is a positive relationship between work-life balance and OCB. 


\subsection{Relationship between $O C B$ and Organizational Performance}

One of the most widely studied topics in organizational behavior research in recent years is organizational citizenship behaviors (Kegans et al., 2012; Wang, 2015; Xerri \& Brunetto, 2013). Due to the importance of OCBs, nowadays, organizations continuously turn their spot light on enhancing the OCBs among employees in order to effectively and efficiently achieve the organizational goals and objectives in the changing competitive business environment. OCB is considered as one of the most favorable workplace behaviors which expected from employees to make organizations more profitable.

In this context, researchers pointed out that OCB should be a major determinant of an employee's job performance (Basu, Pradhan, \& Tewari, 2017; Khaola, 2014; Podsakoff \& MacKenzie, 1997). The employees are the ultimate actors in determining the organization success because they implement the changes in behaviors and routines which are required to achieve the goals of the organization (Perron, Côté, \& Duffy, 2006). Therefore, encouraging OCBs of employees is an important aspect to achieve the organizational goals and objectives (Young et al., 2015). In addition to that Basu et al. (2017) argued that OCB is not a part of the formal organizational structure or reward system, it has far-reaching implications on organizational and individual performance and effectiveness. OCB comprised of five dimensions: (1)altruism (altruism is helping behavior to coworker, supervisor and etc), (2) generalized compliance (employee conscientiousness that surpasses enforceable work standards), (3) sportsmanship (activities such as not complaining or making huge issues out of minor problems or inconveniences), (4) courtesy (act of touching base with others before taking actions or making decisions that would affect their work) and (5) civic virtue (active participation and involvement of employees in company affairs and includes activities such as attending meetings, responding to messages and keeping up with organizational issues) (Basu et al., 2017; Podsakoff \& MacKenzie, 1997; Podsakoff, MacKenzie, Paine, \& Bachrach, 2000). Further, Khaola (2014) argued that, employee who engage in OCBs within the workplace, directly contributes unleash the co-workers performance by help their coworkers; offer them proactive and preventive advice regarding work problems; help prevent, resolve, or mitigate interpersonal conflicts; latitude to incorporate the information and encourage and reinforce their coworkers' achievements (Chiaburu \& Harrison, 2008; Khaola, 2014). In addition to that, motivating OCBs among employees also contributes create a positive organizational climate and work environment. Nowadays, organizations strongly believe that team work is an essential factor to improve the organizational performance. An organization can be considered as collection of people. They have to work as a team to achieve their common goals and purposes (Thevanes \& Arulrajah, 2016). In this trend, Podsakoff and MacKenzie (1997) revealed that OCB leads to superior team performance by enhancing team spirit, morale, and cohesiveness. These dimensions are really fruitful in enhancing team and organizational productivity and definitely these trends may improve employees as well as organizational performance.

Furthermore, researchers revealed that, OCB may also improve performance by enhancing the organization's ability to attract and retain the best people (George \& Bettenhausen, 1990). In addition to that, researchers pointed out that OCB leads to several organizational benefits such as customer satisfaction, sales revenue and financial efficiency (Podsakoff et al., 2000) which turn lead to enrich the overall organizational performance. Moreover, Organ et al. (2006) stated that employees who have a higher level of OCB may express it by showing a personal interest in the work of others, in training new people, in caring for the organization's property, and wishing to remain in their organizations. In addition to that, motivating OCBs among employees contributes to mitigate the turnover intensions and absenteeism of employees. Further, organizations may fully utilize their employees' knowledge and skills by developing OCBs among the employees. Thus, organizations develop and implement the several strategies and practices to foster OCB among employees in order to enrich the organizational performance. Based on the above cited literature evidences, it can be possible to establish a positive relationship between OCB and organizational performance. According to the above literature, this review establishes that OCB has a positive relationship with organizational performance as a third hypothesis of this review:

Hypothesis 3: There is a positive relationship between OCB and organizational performance.

\subsection{OCB Mediates the Relationship between Work-life Balance and Organizational Performance}

In general, when employees feel supported by their organization, they become more committed and satisfied and willing to engage in OCBs at workplace. In addition to that, researchers argued that, work-life balance initiatives and practices of organizations lead to foster OCBs among employees (Beham, 2011; Pradhan et al., 2016). Further, some researchers revealed that without unleashing OCBs among employees, improving organizational performance becomes unrealistic (Basu et al., 2017; Khaola, 2014). Hence, organizations consider more about work-life balance of employees to motivate employees to engage in OCBs within the workplace which ultimately deeply affect their overall organizational performance. According to the above literature, this review establishes that OCB mediates the relationship between work-life balance and organizational performance as the fourth hypothesis of this review:

Hypothesis 4: OCB mediates the relationship between work-life balance and organizational performance.

Hence, based on the review, this paper proposes a conceptual model that shows the relationships among environmental training, and environmental attitude of employee and environmental orientation of organization (see Figure 1).

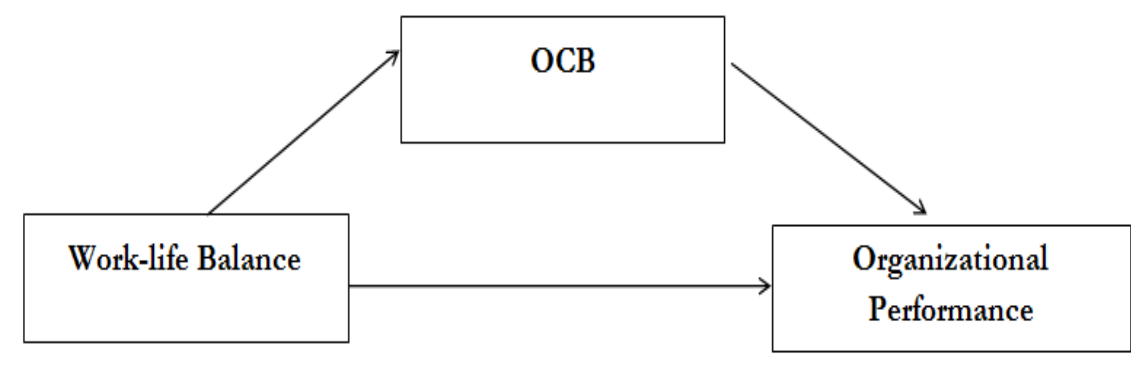

Figure-1. Conceptual framework. 


\section{Methodology}

\subsection{Sampling and Data Collection}

The empirical data for the current study were collected from selected private banks in Batticaloa district of Sri Lanka. The total population for the study was 210 employees of selected private banks in Batticaloa. Out of these, 166 employees were selected as sample to conduct this research by using disproportionate stratified sampling method, because to assure representation of employees belonging to different grades in the selected banks. This study depends on primary data. The data of this study were collected from the respondents through structured questionnaire. In order to ensure the content validity of the scale used, it is advised to largely adapt the items for each construct from prior researches (Luarn \& Lin, 2005). Therefore, 25 survey items for each construct in the questionnaire were adapted from prior researches. The questionnaire contained questions relating to work-life balance and OCB and organizational performance.

\subsection{Measures}

All constructs were measured with multiple items developed and tested in previous studies. Each item was measured on a five-point Likert-type scale anchored by "strongly disagree ee and "strongly agree" response options. The researchers used an instrument adapted from past review works of Banu and Duraipadiyan (2014). This instrument can be used to measure work-life balance in an organization that consists of eleven question items in five Point Likert-scales. This instrument had a Cronbache's alpha of 0.89 which is higher than 0.70. Hence, this instrument had a good reliability. The authors used an instrument adapted from past research works of Somech and Ron (2007) to quantify the OCB. This instrument had a Cronbach's alpha of 0.88, which is higher than 0.70. Hence, this instrument had good reliability. The instrument had a good degree of reliability with a Cronbach's alpha of 0.87. The researchers used an instrument adapted from past research works of Santos and Brito (2012) to quantify the organizational performance. This instrument had a Cronbach's alpha of 0.69 which is lower than 0.70. However, according to Bowling (2002) an alpha of 0.5 or higher is considered a sign of acceptable internal consistency. Hence, this instrument had used in this study.

\subsection{Data Analysis Techniques}

Correlation analysis was conducted to examine the relationship between the variables (Jahangir \& Begum, 2008). According to Sekaran (2000) the correlation coefficient value (r) ranges from 0.10 to 0.29 is considered weak, from 0.30 to 0.49 is considered medium and from 0.50 to 1.0 is considered strong. However, according to Field (2005) correlation coefficient should not go beyond 0.8 to avoid multicollinearity. The correlation matrix shows that multi-collinearity does not threaten the validity of the data.

To test the relationship between work-life balance and organizational performance $\left(\mathrm{H}_{1}\right)$, work-life balance and $\operatorname{OCB}\left(\mathrm{H}_{2}\right)$ and OCB and organizational performance $\left(\mathrm{H}_{3}\right)$, as well as mediating effect of OCB on the relationship between work-life balance and organizational performance $\left(\mathrm{H}_{4}\right)$, correlations and simple mediation analyses were used. This method was proposed by Baron and Kenny (1986) to examine the mediating effect. In conducting simple mediation analysis, series of regressions were performed. The first involved regressing the dependent variable on independent variable, then independent variable on mediating variable and hereafter mediating variable on dependent variable and finally performing a multiple regression analysis with independent variable and mediating variable on dependent variable.

\section{Findings of the Study \\ 4.1. Correlation Analysis}

Table 1 shows the correlation matrix. Correlation analysis illustrates that work-life balance has a moderate positive correlation with organizational performance. Correlation analysis also shows that there is a strong positive correlation exists between work-life balance and OCB. Further, correlation analysis indicated that OCB has a strong positive correlation with organizational performance.

Table-1. Correlation Matrix

\begin{tabular}{r|l|c|c}
\hline \multicolumn{2}{l|}{ Variables } & $\mathbf{1}$ & $\mathbf{2}$ \\
\hline 1 & Work-life balance & & \\
\hline 2 & OCB & $0.669^{* *}$ & \\
\hline 3 & Organizational Performance & $0.473^{* *}$ & $0.522^{* *}$ \\
\hline Notes: $\mathrm{N}=108,{ }^{* *}$ Correlation is significant at the 0.01 level (2-tailed), ${ }^{*}$ Correlation is significant at the 0.05 level $(2$
\end{tabular}
tailed).

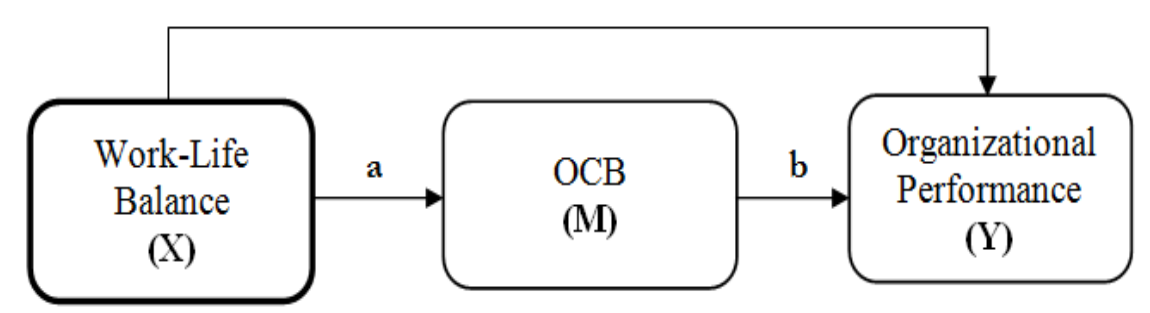

Figure-2. Simple Mediation Model.

Figure 2 shows the simple mediation model of the study. Paths a and b are called direct effects. The meditational effect, in which X leads to $\mathrm{Y}$ through $\mathrm{M}$, is called the indirect effect. The indirect effect represents the portion of the relationship between X and Y that is mediated by M. Baron and Kenny (1986) proposed a four-step 
approach in which several regression analyses are conducted and significance of the coefficients is examined at each step. Take a look at the Table 2 below to follow the description.

Table-2. Four step approach for simple mediation analysis.

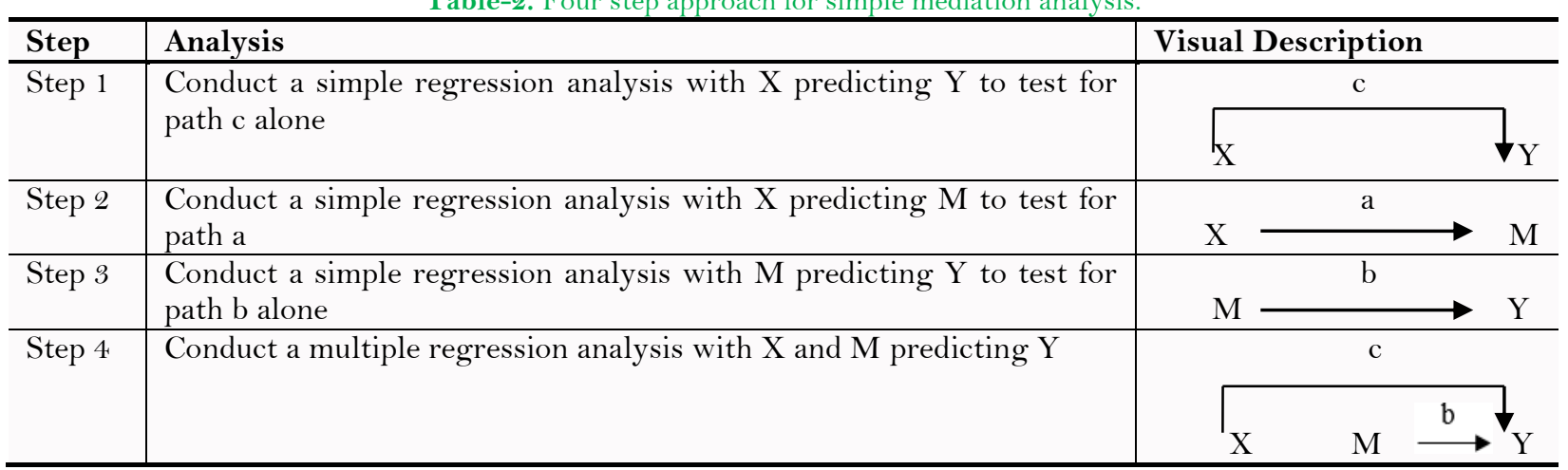

Source: Adapted from Baron and Kenny (1986).

Table 2 shows the four-step approach for simple mediation analysis. The purpose of steps 1-3 is to establish that zero-order relationships among the existing variables. If one or more of these relationships are non-significant that mediation is not possible or likely. Assuming there are significant relationships from steps 1 through 3 , one proceeds to step 4 . In the step 4 model, work-life balance $(\mathrm{X})$ is no longer significant when OCB $(\mathrm{M})$ is controlled, so, the findings support full mediation.

Table-3. Significance value for simple mediation analysis.

\begin{tabular}{c|l|l|c}
\hline Step & Independent Variable & Dependent Variable & Sig \\
\hline 1 & Work-life Balance & Organizational Performance & 0.000 \\
\hline 2 & Work-life Balance & OCB & 0.000 \\
\hline 3 & OCB & Organizational Performance & 0.000 \\
\hline 4 & Work-life balance & Organizational Performance & 0.254 \\
\hline
\end{tabular}

Table 3 shows the simple mediation analysis of the study. From step 1 to step 3, the relationship between the variables are significant as sig value is less than 0.05. In the step 4, OCB (0.000) is significant while work-life balance $(0.254)$ is insignificant. Hence, the relationship between e-HRM and environmental performance is mediated by OCB.

\section{Discussion}

Basically, this review deals with three main concepts. They are work-life balance, OCB, and job performance. The findings of the study suggest that there are positive relationships between the work-life balance and organizational performance, work-life balance and OCB and OCB and organizational performance. Further, findings of the study revealed that, OCB mediates relationship between work-life balance and organizational performance.

The work-life balance promoting practices aims to shapes the positive work-related attitude of employees such as job satisfaction, organizational commitment, job involvement. In this regard, recently organizations start up to recruit and select appropriate people who are closest to the workplace or organization to eliminate the work-life conflict of employees. For the employees who work in the home town, the work-life conflict is much less than the others whose work site is far away from home (Thevanes \& Arurajah, 2017). Further, an employee can work around the clock to improve the productivity. Most of the employees who work in the out stations usually feel homesick and don't shows any interest in their works. Hence, this suggested that organizations take necessary steps to up-lift the work-life balance of employees in order to improve job satisfaction of employees. Ultimately, this trend encourages the employees to foster the OCBS in the workplace. In an organizational context, satisfied, committed and involved workforce more likely to engage in OCBs within the workplace. Without foster the OCBs among organization's employees improving the organizational performance become unrealistic. Further, work-life balance promoting practices really fruitful in creating and sustaining happy and motivated workforce by allowing them to balance their family responsibilities as well as work responsibilities. Overall, this trend contributes to improve the organizational performance.

\section{Conclusion}

The empirical data for the current study were collected from selected private banks in Batticaloa district of Sri Lanka. Based on the empirical finding of the study, there is positive and significant relationship exists between work-life balance and organizational performance. Similarly, there is positive and significant relationship exists between work-life balance and $\mathrm{OCB}$ as well as $\mathrm{OCB}$ and organizational performance. Moreover, findings of the study revealed that, OCB mediates the relationship between work-life balance and organizational performance.

\section{Limitations and Future Studies}

The current study is a cross-sectional study. Therefore, it is important for future studies to validate the current findings in a longitudinal design could be more appropriate than cross-sectional ones for establishing casual inferences based on preexisting theory and empirical data (Chiaburu \& Harrison, 2008). The current study only applies a quantitative research design. Therefore, future studies may consider collecting deeper data from the respondents. The use of both qualitative and quantitative methods would provide an opportunity for more depth and richer explanations regarding the relationships among work-life balance, OCB and organizational performance. In addition to that, future studies have the further opportunities to consider the antecedent variables related to this 
study. The findings of this study are methodologically limited by restrictions imposed by the study in selected private banks in Sri Lanka, which not permit the generalization of findings. In order to overcome this limitation, broader studies are suggested. Also, future studies could replicate the proposed model in various sectors in Sri Lanka.

\section{References}

Allen, T. D. (2001). Family-supportive work environments: The role of organizational perceptions. Journal of Vocational Behavior, 58(3), 414435. Available at: https://doi.org/10.1006/jvbe.2000.1774.

Arulrajah, A. A., \& Opatha, H. (2012). An exploratory study on the personal qualities/Characteristics expected by the organisations for key HRM jobs in Sri Lanka. Sri Lankan Journal of Human Resource Management, 3(1), 32-48.

Banu, A. R., \& Duraipadiyan, K. (2014). Development of an instrument to measure work life balance of it professionals in Chennai. International Journal of management, 5(11), 21-33.

Bardoel, E. A., \& Drago, R. (2016). Does the quality of information technology support affect work-life balance? A study of Australian physicians. The International Journal of Human Resource Management, 27(21), 2604-2620. Available at: 10.1080/09585192.2016.1232293.

Baron, R. M., \& Kenny, D. A. (1986). The moderator-mediator variable distinction in social psychology research: Conceptual, strategic and statistical considerations. Journal of Personality and Social Psychology, 51(6), 1173-1182. Available at: http://dx.doi.org/10.1037/0022-3514.51.6.1173.

Basu, E., Pradhan, R. K., \& Tewari, H. R. (2017). Impact of organizational citizenship behavior on job performance in Indian healthcare industries. International Journal of Productivity and Performance Management, 66(6), 780-796. Available at: https://doi.org/10.1108/IJPPM-02-2016-0048.

Beham, B. (2011). Work-family conflict and organisational citizenship behaviour: Empirical evidence from Spanish employees. Community, Work \& Family, 14(1), 63-80. Available at: 10.1080/13668803.2010.506034.

Bowling, A. (2002). Research methods in health: Investigating health and health services (2nd ed.). Buckingham: Open University Press.

Chan, X. W., Kalliath, T., Brough, P., Siu, O.-L., O’Driscoll, M. P., \& Timms, C. (2016). Work-family enrichment and satisfaction: The mediating role of self-efficacy and work-life balance. The International Journal of Human Resource Management, 27(15), $1755-1776$. Available at: 10.1080/09585192.2015.1075574.

Chiaburu, D. S., \& Harrison, D. A. (2008). Do peers make the place? Conceptual synthesis and meta-analysis of coworker effects on perceptions, attitudes, OCBs, and performance. Journal of Applied psychology, 93(5), 1082-1 103.

Cieri, H., Holmes, B., Abbott, J., \& Pettit, T. (2005). Achievements and challenges for work/life balance strategies in Australian organizations. The International Journal of Human Resource Management, 16(1), 90-103. Available at: $10.1080 / 0958519042000295966$.

Edwards, T., \& Kuruvilla, S. (2005). International HRM: National business systems, organizational politics and the international division of labour in MNCs. The International Journal of Human Resource Management, 16(1), 1-21. Available at: $10.1080 / 0958519042000295920$.

Field, A. (2005). Discovering statistics using SPSS (2nd ed.). London: Sage Publication.

Fischlmayr, I. C., \& Kollinger, I. (2010). Work-life balance-a neglected issue among Austrian female expatriates. The International Journal of Human Resource Management, 21(4), 455-487. Available at: 10.1080/09585191003611978.

Fleetwood, S. (2007). Why work-life balance now? The International Journal of Human Resource Management, 18(3), 387-400. Available at: $10.1080 / 09585190601167441$.

Galinsky, E., Bond, J. T., \& Hill, E. J. (2004). When work works: A status report on workplace flexibility. New York: Families and Work Institute.

George, J. M., \& Bettenhausen, K. (1990). Understanding prosocial behavior, sales performance, and turnover: A group-level analysis in a service context. Journal of Applied Psychology, 75(6), 698-709.

Greenhaus, J. H., Collins, K. M., \& Shaw, J. D. (2003). The relation between work-family balance and quality of life. Journal of Vocational Behavior, 63(3), 510-531. Available at: 10.1016/S0001-8791(02)00042-8.

Hayman, J. R. (2009). Flexible work arrangements: Exploring the linkages between perceived usability of flexible work schedules and work/life balance. Community, Work \& Family, 12(3), 327-338. Available at: 10.1080/13668800902966331.

Heywood, J. S., Siebert, W. S., \& Wei, X. (2010). Work-life balance: Promises made and promises kept. The International Journal of Human Resource Management, 21(11), 1976-1995. Available at: 10.1080/09585192.2010.505098.

Hoffman, B. J., Blair, C. A., Meriac, J. P., \& Woehr, D. J. (2007). Expanding the criterion domain? A quantitative review of the OCB literature. Journal of Applied Psychology, 92(2), 555. Available at: https://doi.org/10.1037/002 1-9010.92.2.555.

Hyman, J., \& Summers, J. (2007). Work and life: Can employee representation influence balance? Employee Relations, 29(4), 367-384. Available at: http://dx.doi.org/10.1108/01425450710759208.

Jahangir, N., \& Begum, N. (2008). The role of perceived usefulness, perceived ease of use, security and privacy, and customer attitude to engender customer adaptation in the context of electronic banking. African Journal of Business Management, 2(2), 32-40.

Kegans, L., McCamey, R. B., \& Hammond, H. (2012). Organizational citizenship behavior and work experience. Hospital Topics, 90(3), 74-81. Available at: 10.1080/00185868.2012.721699.

Khaola, P. P. (2014). The relationships among students' commitment, self-esteem, organisational citizenship behaviour and academic performance. Africa Education Review, 11(2), 119-132. Available at: https://doi.org/10.1080/18146627.2014.927144.

Konrad, A. M., \& Mangel, R. (2000). The impact of work-life programs on firm productivity. Strategic Management Journal, 21(12), 12251237 .

Koopmans, L., Bernaards, C. M., Hildebrandt, V. H., Schaufeli, W. B., de Vet Henrica, C., \& van der Beek, A. J. (2011). Conceptual frameworks of individual work performance: A systematic review. Journal of Occupational and Environmental Medicine, 53(8), 856866.

Lambert, S. J. (2000). Added benefits: The link between work-life benefits and organizational citizenship behavior. Academy of management Journal, 43(5), 801-815. Available at: https://doi.org/10.5465/1556411.

Lambert, E. G., Hogan, N. L., \& Griffin, M. L. (2008). Being the good soldier: Organizational citizenship behavior and commitment among correctional staff. Criminal Justice and Behavior, 35(1), 56-68. Available at: https://doi.org/10.1 177/0093854807308853.

Lambert, E. G., Kelley, T., \& Hogan, N. L. (2013). Work-family conflict and organizational citizenship behaviors. Journal of Crime and Justice, 36(3), 398-417. Available at: 10.1080/0735648X.2012.706402.

Luarn, P., \& Lin, H. H. (2005). Toward an understanding of the behavioral intention to use mobile banking. Computers in Human Behavior, $21(6), 873-891$.

McCarthy, A., Cleveland, J. N., Hunter, S., Darcy, C., \& Grady, G. (2013). Employee work-life balance outcomes in Ireland: A multilevel investigation of supervisory support and perceived organizational support. The International Journal of Human Resource Management, 24(6), 1257-1276. Available at: https://doi.org/10.1080/09585192.2012.709189.

McNall, L. A., Masuda, A. D., \& Nicklin, J. M. (2009). Flexible work arrangements, job satisfaction, and turnover intentions: The mediating role of work-to-family enrichment. The Journal of Psychology, 144(1), 61-81. Available at: 10.1080/00223980903356073.

Meijerink, J., Bos-Nehles, A., \& de Leede, J. (2018). How employees' pro-activity translates high-commitment HRM systems into work engagement: The mediating role of job crafting. The International Journal of Human Resource Management, 1-26. Available at: https://doi.org/10.1080/ 09585192.2018.1475402.

Moorman, R. H., \& Blakely, G. L. (1995). Individualism-collectivism as an individual difference predictor of organizational citizenship behavior. Journal of organizational behavior, 16(2), 127-142.

Naithani, P. (2010). Overview of Work-life balance discourse and its relevance in current economic scenario. Asian Social Science, 6(6), 148155 . 
Nawab, S., \& Iqbal., S. (2013). Impact of work-family conflict on job satisfaction and life satisfaction. Journal of Basic and Applied Scientific Research, 3(7), 101-110.

Organ, D. W., Podsakoff, P. M., \& MacKenzie, S. B. (2006). Organizational citizenship behavior: Its nature, antecedents, and consequences. Thousand Oaks, CA: Sage.

Parakandi, M., \& Behery, M. (2016). Sustainable human resources: Examining the status of organizational work-life balance practices in the United Arab Emirates. Renewable and Sustainable Energy Reviews, 55, 1370-1379. Available at: 10.1016/j.rser.2015.07.095.

Perron, G. M., Côté, R. P., \& Duffy, J. F. (2006). Improving environmental awareness training in business. Journal of Cleaner Production, 14(67), 551-562. Available at: http://dx.doi.org/10.1016/j.jclepro.2005.07.006.

Podsakoff, P. M., \& MacKenzie, S. B. (1997). Impact of organizational citizenship behavior on organizational performance: A review and suggestion for future research. Human Performance, $1 O(2), 133-151$. Available at: 10.1207/s 15327043hup 1002_5.

Podsakoff, P. M., MacKenzie, S. B., Paine, J. B., \& Bachrach, D. G. (2000). Organizational citizenship behaviors: A critical review of the theoretical and empirical literature and suggestions for future research. Journal of Management, 26(3), 513-563.

Pradhan, R. K., Jena, L. K., \& Kumari, I. G. (2016). Effect of work-life balance on organizational citizenship behaviour: Role of organizational commitment. Global Business Reviere, 17 (3_suppl), 15S-29S. Available at: https://doi.org/10.1177/0972150916631071.

Richman, A. (2006). Everyone wants an engaged workforce how can you create it. Workspan, 49(1), 36-39.

Robbins, S. P., \& Judge, T. A. (2013). Fundamentals of organizational behaviour (15th ed.): Pearson Education Canada.

Santos, J. B., \& Brito, L. A. L. (2012). Toward a subjective measurement model for firm performance. BAR-Brazilian Administration Revierw, 9(6), 95-1 17. Available at: https://doi.org/10.1590/s1807-76922012000500007.

Sekaran, U. (2000). Research methods for business: A skill-building approach (3rd ed.). New York: Hermitage Publishing Services.

Somech, A., \& Drach-Zahavy, A. (2004). Exploring organizational citizenship behaviour from an organizational perspective: The relationship between organizational learning and organizational citizenship behaviour. Journal of Occupational and Organizational Psychology, 77(3), 281-298. Available at: https://doi.org/10.1348/0963179041752709.

Somech, A., \& Ron, I. (2007). Promoting organizational citizenship behavior in schools: The impact of individual and organizational characteristics. Educational Administration Quarterly, 43(1), 38-66.

Thevanes, N., \& Arulrajah, A. A. (2016). The relationships among environmental training, environmental attitude of employee, environmental behavior of employee and environmental orientation of organization: A review of literature. Paper presented at the Proceedings of 13 th International Conference on Business Management (ICBM), University of Sri Jayewardenepura.

Thevanes, N., \& Arurajah, A. A. (2017). The search for sustainable human resource management practices: A review and reflections. Paper presented at the Proceedings of 14th International Conference on Business Management (ICBM), University of Sri Jayewardenepura.

Thevanes, N., \& Mangaleswaran, T. (2018). Relationship between work-life balance and job performance of employees. IOSR Journal of Business and Management, 20(5), 11-16. Available at: 10.9790/487X-2005011116.

Tsui-Hsu Tsai, T., \& Jing Lin, A. (2014). Do psychological contract and organizational citizenship behavior affect organizational performance in non-profit organizations? Chinese Management Studies, 8(3), 397-417. Available at: https://doi.org/10.1108/CMS05-2013-0090.

Turnipseed, D. L., \& Rassuli, A. (2005). Performance perceptions of organizational citizenship behaviours at work: A bi-level study among managers and employees. British Journal of Management, 16(3), 231-244. Available at: https://doi.org/10.1111/j.14678551.2005.00456.x.

Vigoda-Gadot, E., \& Beeri, I. (2011). Change-oriented organizational citizenship behavior in public administration: The power of leadership and the cost of organizational politics. Journal of Public Administration Research and Theory, 22(3), 573-596. Available at: https://doi.org/10.1093/jopart/muro36.

Waller, A. D., \& Ragsdell, G. (2012). The impact of e-mail on work-life balance. Aslib Proceedings, 64(2), 154 - 177. Available at: http://dx.doi.org/10.1108/00012531211215178.

Wang, P., \& Walumbwa, F. O. (2007). Family-friendly programs, organizational commitment, and work withdrawal: The moderating role of transformational leadership. Personnel Psychology, 60(2), 397-427. Available at: https://doi.org/10.1111/j.1744-6570.2007.00078.x.

Wang, Y. (2015). Examining organizational citizenship behavior of Japanese employees: A multidimensional analysis of the relationship to organizational commitment. The International Journal of Human Resource Management, 26(4), 425-444. Available at: 10.1080/09585192.2011.560882.

WFD Consulting. (2007). The new career paradigm: Flexibility briefing. Newton, MA: WFDConsulting.

Wheatley, D. (2012). Good to be home? Time-use and satisfaction levels among home-based teleworkers. New Technology, Work and Employment, 27(3), 224-241. Available at: https://doi.org/10.1111/j.1468-005x.2012.00289.x.

Williams, S., \& Shiaw, W. T. (1999). Mood and organizational citizenship behavior: The effects of positive affect on employee organizational citizenship behavior intentions. The Journal of Psychology, 133(6), 656-668. Available at: https://doi.org/10.1080/00223989909599771.

Winefield, H. R., Boyd, C., \& Winefield, A. H. (2014). Work-family conflict and well-being in university employees. The Journal of Psychology, 148(6), 683-697. Available at: 10.1080/00223980.2013.822343.

Xerri, M. J., \& Brunetto, Y. (2013). Fostering innovative behaviour: The importance of employee commitment and organisational citizenship behaviour. The International Journal of Human Resource Management, 24(16), 3163-3177. Available at: $10.1080 / 09585192.2013 .775033$.

Young, W., Davis, M., McNeill, I. M., Malhotra, B., Russell, S., Unsworth, K., \& Clegg, C. W. (2015). Changing behaviour: Successful environmental programmes in the workplace. Business Strategy and the Environment, 24(8), 689-703. Available at: https://doi.org/10.1002/bse.1836.

Zhao, H., Wu, J., Sun, J. M., \& Chen, C. W. (2012). Organizational citizenship behavior in Chinese society: A reexamination. The International Journal of Human Resource Management, 23(19), 4145-4165. Available at: 10.1080/09585192.2012.669786. 